\title{
Japanese Junior High School English Textbook Input and Wh-Question Formulation
}

\section{Paul A. Lyddon \\ University of Shizuoka \\ Hiromu Okamura \\ Shizuoka University}

\section{Reference Data:}

Lyddon, P. A., \& Okamura, H. (2020). Japanese junior high school English textbook input and wh-question formulation. In P. Clements, A. Krause, \& R. Gentry (Eds.), Teacher efficacy, learner agency. Tokyo: JALT. https://doi.org/10.37546/JALTPCP2019-07

Second language acquisition of English wh-questions is complicated by asymmetries among different $w h$-question types. In a study of the $w h$-interrogative production of Japanese junior high school (JHS) learners, Hasebe and Maki (2014) found a disordinal interaction between wh-question type and English proficiency level. They also noted an unexplained tendency for more advanced learners to over-insert do. Connecting these findings, the present investigation hypothesized greater learner exposure to wh-questions with do at higher levels of study, which was evaluated by comparing the proportions of relevant wh-question types across the three grade levels of three popular ministry-approved JHS English textbooks. Although failing to support the research hypothesis, the results revealed a scarcity of noncopular main verb wh-subject questions. Given retrograde development of this particular question type, these findings suggest a possible need to explicitly sensitize learners to the distinctions between various wh-question types as well as provide additional implicit exposure to them.

第二言語習得研究では、英語のwh疑問文の種類によって習得速度に違いがあることが報告されている。Hasebe \& Maki (2014) による日本人中学生を対象にした調查では、wh疑問文の種類と英語の上達度の間に非順序的な交互作用があ ることに加えて、初級の学習者に比べ、中上級の学習者は主語疑問文でdo挿入を過剩に適用する傾向があることが分かった。 この結果をもとに、中上級の学習者はdo挿入があるwh疑問文のインプットを、初級者よりも多く受けていると考え、日本の中 学校で使用されている教科書に掲載されていた疑問文の例を調査した。その結果、インプットの量が影響しているという仮説 は支持されなかったが、全体として主語疑問文の数が少ないことが分かった。Hasebeらで観察された学習者の主語疑問文の
習得に対し、本研究の結果は、学校教育の場において主語疑問文のインプットを増やすことや、疑問文の種類の違いを明示的 に指導する必要性があることを示唆している。

h-questions are among the most difficult types of English interrogative
expressions to master (Pica, 2003). In fact, they actually comprise several subtypes, including adjunct and argument questions, the latter of which can be further subdivided into subject and object questions. Moreover, asymmetries in the development of these various wh-question subtypes have been observed in both English as a first language (e.g., de Villiers, 1991; Ervin-Tripp, 1970; Stromswold, 1990) and as a second (J.H. Lee, 2009; S.-Y. Lee, 2008), with wh-argument questions outpacing wh-adjuncts and wh-subject questions outpacing wh-object questions. In a study of Japanese junior high school (JHS) learners, however, Hasebe and Maki (2014) reported an interaction between the rate of wh-question subtype development and level of English proficiency, whereby beginners predictably demonstrated greater mastery of wh-subject questions before whobject questions and wh-argument questions before $w h$-adjuncts, but intermediate and advanced learners showed just the opposite. These researchers also indicated a tendency for intermediate and advanced learners to overgeneralize the use of $d o$. Though Hasebe and Maki (2014) did not suggest any connection, the investigators in the present study hypothesized frequency effects, namely disproportionately greater exposure to whquestions involving $d o$, as an explanation for the apparent retrograde development of whsubject questions with respect to overall language progress.

To test this hypothesis, a comparison of the number of wh-questions with and without do across all three grade levels of three popular Japanese ministry-approved JHS English textbooks to determine whether JHS learners were potentially exposed to greater proportions of the former after their first year of study. Following a brief review of previous research on asymmetries in wh-question development, we present a detailed description of the methodology employed in the current investigation as well as an analysis of the results. We then discuss an alternate possible explanation for Japanese 
JHS learners' apparently asymmetrical development of wh-questions with and without do. Independent of the actual cause of asymmetry, We also provide practical advice for explicit pedagogical intervention. The paper concludes with a statement of some of the current study's limitations before a summary of its main findings and their implications.

\section{Literature Review}

Interrogative statements (i.e., questions) are generally introduced early in L2 English instruction. However, their correct formulation appears to develop in stages, beginning with the use of single words (e.g., There?) and fixed expressions (e.g., What's wrong?) and culminating in that of tags (e.g., You're a student, aren't you?), negative questions (e.g., Aren't you coming?), and embedded questions (e.g., Do you know where she lives?) (Pica, 2003). At both the antepenultimate and penultimate tiers of the difficulty-of-acquisition hierarchy is inversion, with well-formed copular questions (e.g., What is her hobby?) emerging before questions with verbs requiring do-support (e.g., What does she study?).

In the case of wh-questions, however, a number of question subtypes must also be recognized. For instance, a distinction should be made between wh-argument questions and wh-adjunct questions. Argument questions (e.g., who, what) target core information that is necessary to the completion of the verb, whereas adjunct questions (e.g., when, where, how, why) target nonobligatory additional information. L1 English studies (e.g., de Villiers, 1991; Stromswold, 1990) have shown clear asymmetries in the development of these two question types, the former exhibiting inversion before the latter. S.-Y. Lee (2008) corroborated these findings in L2 English with Korean university learners, who correctly recognized the ungrammaticality of uninverted interrogatives involving wharguments (e.g., What you are reading in the library?) significantly better than they did those containing wh-adjuncts (e.g., Why you are jumping on the bed?). Moreover, she concurred with generative theorists in concluding that this finding was consistent with a structure-based account of language development.

Within the category of argument questions, however, another important distinction needs to be made, namely the difference between $w h$-subject questions (e.g., Who came to the party? What happened?) and wh-object questions (e.g., Who did you see? What did you do?). Subject questions have long been shown to develop faster than object questions in children learning English as their first language (e.g., Ervin-Tripp, 1970), and J.-H. Lee (2009) reported a similar developmental tendency among adolescent and adult Korean learners of L2 English, which she attributed to the computational complexity of whextraction (i.e., movement of the $w h$-word to the front of the question from the position of the word or expression it represents in the answer).
Hasebe and Maki (2014) conducted a study to investigate both these types of whquestion asymmetry with Japanese JHS English learners. The participants were given an in-house proficiency test called the junior Minimal English Test (jMET) and categorized as either beginner, intermediate, or advanced on the basis of their test scores. They were then given the specially developed $W h$-Interrogative Formation Test, consisting of 60 declarative statements designed to elicit 12 instances each of five types of question: yes/ no, wh-subject, wh-object, when, and why.

Based on the findings of S.-Y. Lee (2008) and J.-H. Lee (2009), one would expect to see wh-argument questions develop before $w h$-adjuncts and $w h$-subject questions before wh-objects. In other words, the developmental sequence would be from wh-subjects to $w h$-objects to $w h$-adjuncts. However, in their comparison of $w h$-arguments (i.e., $w h$-subject and $w h$-object questions collectively) versus wh-adjuncts (i.e., when and why), Hasebe and Maki (2014) found that beginners exhibited only nominally better performance on the former (e.g., Who read the book? What did John read?), whereas intermediate and advanced learners performed statistically significantly better on the latter (e.g., When/Why did John read the book?). In a separate comparison of the two wh-argument question types, although beginners predictably had greater ease with whsubjects, intermediate and advanced learners unexpectedly showed greater facility with wh-objects. Though Hasebe and Maki (2014) did not report any inferential testing in this regard, their descriptive statistics suggest that, at every proficiency level, wh-object questions developed at a similar rate to $w h$-adjunct questions. As such, the apparent asymmetry between $w h$-arguments and $w h$-adjuncts was likely a statistical artifact due to averaging the scores on $w h$-subject and $w h$-object question performance.

A synthesis and restatement of these findings would be that beginners showed greater development of wh-subject questions than of wh-object and wh-adjunct questions, but intermediate and advanced learners showed greater development of wh-object and whadjunct questions than of wh-subject questions. In other words, less proficient learners more accurately produced questions that did not involve wh-movement, whereas more proficient learners more accurately formulated those that did. Hasebe and Maki (2014) explained the apparent reversal with respect to the facility of subject questions as attributable to overgeneralization of $d o$ insertion once it is acquired in association with wh-words, but they gave no account as to why such might be the case.

Note, however, that all 48 wh-question items on Hasebe and Maki's (2014) WhInterrogative Formation Test involved only noncopular (i.e., not a form of $b e$ ) verbs without auxiliaries (i.e., helping verbs be or have or modal verbs such as can, could, will, or would). Moreover, with but a few uncommon exceptions (e.g., Who said what?), 
noncopular main verb wh-adjunct and wh-object questions always require do insertion, whereas analogous wh-subject questions never do. Ellis (2002) characterized language learning as an implicit process of strengthening associations between co-occurring elements and exploiting probabilistic knowledge of them. Thus, the overuse of $d o$ in this case might hypothetically stem from the overall relative statistical likelihood of its cooccurrence with wh-words. In other words, if the number of noncopular main verb whadjunct and wh-object questions (i.e., those with $d o$ ) in the input sufficiently outweighs that of their wh-subject counterparts (i.e., those without do), the former could effectively condition the use of $d o$ after all wh-words in noncopular main verb wh-questions. As such, the research question for the present investigation was the following:

RQ. Are intermediate- and advanced-level Japanese JHS English learners exposed to comparatively greater proportions of noncopular main verb wh-adjunct and wh-object questions than their beginner-level counterparts?

\section{Method}

As our measure of learner exposure to the relevant question forms, we counted their appearances in a sample of the most popular Japanese ministry-approved JHS English textbook series, including Sunshine (Kairyudo 2016a, 2016b, 2016c), New Crown (Sanseido 2016a, 2016b, 2016c) and New Horizon (Tokyo Shoseki 2015a, 2015b, 2015c). The rationale was that although individual teachers undoubtedly supplement their instruction with other learning materials, government-sanctioned textbooks, as a general requirement, are arguably the most common feature of all Japanese school learners' experience. As proxies for beginner-, intermediate-, and advanced-level language proficiency, we used 1st-, 2nd-, and 3rd-year coursebooks. Although this correspondence is admittedly imperfect, one would logically expect language proficiency to positively correlate with years of study. After identifying all 2,078 instances of interrogative expressions in all three volumes of each series, we then entered them into a database and tagged them for wh-question word and expression type.

Mirroring the items on Hasebe and Maki's (2014) Wh-Interrogative Formation Test, wh-question words were categorized as who, what, when, or why. All remaining cases (e.g., how, which, whose) were labeled other.

The expressions were classified into three different types, as follows:

1. noncopular main verb wh-questions without do (e.g., What makes you happy?);
2. noncopular main verb wh-questions with do (e.g., What do you have for breakfast?); and

3. all other interrogative expressions, including noncanonical questions, such as intonational questions (e.g., Turn left?), tag questions (e.g., He knows your number, doesn't he?), and other constructions lacking a main verb (e.g., Really? Where?); questions involving a copular main verb (i.e., What's your name?); and questions involving an auxiliary verb other than $d o$ (e.g., What were you doing?).

For the purpose of answering the research question, only instances of the first two expression types containing who, what, when, or why were included in the data analysis, as these were the only ones involving wh- and do insertion in the findings of Hasebe and Maki (2014). After the elimination of all other cases, a total of 346 items (17\% of the original number) remained.

\section{Results}

As the exact number of instances of each wh-word within each question type was small but different across textbooks within grade levels, each textbook was considered separately so as not to assume statistical equivalence of the distributions for all the textbooks within each level. Nevertheless, as Table 1 illustrates, although the total number of nonsubject wh-questions (i.e., those with do) actually decreases with level in the case of the New Crown series (i.e., from 48 to 38 and 38), the proportion with respect to $w$-subject questions (i.e., those without do) exhibits a similar pattern at each grade level for all three series. In the level 1 textbooks, nonsubject wh-questions represented $94 \%$ to $100 \%$ of all wh-questions with noncopular main verbs and no auxiliaries. The ranges for levels 2 and 3 were $87 \%$ to $94 \%$ and $84 \%$ to $87 \%$, respectively.

Moreover, Table 1 also shows that nonsubject wh-questions in the Sunshine series decreased from $94 \%$ at level 1 to $92 \%$ at level 2 and then to $86 \%$ at level 3 . In the New Horizon series, the decrease was even more pronounced, from $100 \%$ to $94 \%$ to $84 \%$. Although the numbers for levels 2 and 3 of the New Crown series were identical at $87 \%$, they were still below the initial $98 \%$ at level 1 . 
Table 1. Subject vs. Nonsubject Wh-Questions With Noncopular Main Verbs

\begin{tabular}{lccccccccccc}
\hline & \multicolumn{4}{c}{ Subject $(-d o)$} \\
series & level & who & what & total & $\%$ & who & what & when & why & total & $\%$ \\
\hline S & 1 & 2 & 0 & 2 & 6 & 0 & 21 & 6 & 6 & 33 & 94 \\
& 2 & 2 & 1 & 3 & 8 & 0 & 27 & 0 & 11 & 38 & 92 \\
& 3 & 1 & 5 & 6 & 14 & 0 & 31 & 4 & 9 & 44 & 86 \\
& & & & & & & & & & & \\
NC & 1 & 1 & 0 & 1 & 2 & 0 & 35 & 9 & 4 & 48 & 98 \\
& 2 & 3 & 2 & 5 & 13 & 1 & 30 & 2 & 5 & 38 & 87 \\
& 3 & 1 & 4 & 5 & 13 & 0 & 30 & 0 & 8 & 38 & 87 \\
& & & & & & & & & & & \\
NH & 1 & 0 & 0 & 0 & 0 & 0 & 16 & 1 & 0 & 17 & 100 \\
& 2 & 2 & 0 & 2 & 6 & 2 & 18 & 3 & 6 & 29 & 94 \\
& 3 & 1 & 4 & 5 & 16 & 0 & 24 & 1 & 7 & 32 & 84 \\
\hline
\end{tabular}

Note. $\mathrm{S}=$ Sunshine, $\mathrm{NC}=$ New Crown, $\mathrm{NH}=$ New Horizon .

\section{Discussion}

In short, the data do not support our hypothesis of comparatively greater proportions of nonsubject wh-question words appearing at the higher levels of study. In fact, they suggest just the opposite. A close look at the wh-subject question numbers, however, strikingly reveals that each of these three textbook series provides a total of only 7 to 11 instances of noncopular main verb wh-subject questions across all three levels. For example, in the Sunshine series the number goes from two such wh-subject questions at level 1 to three at level 2 to six at level 3. In the New Crown and New Horizon series, the numbers are 1-5-5 and 0-2-5, respectively. In other words, Japanese JHS English learners relying primarily on their textbooks for input would have very little evidence that formulating ordinary wh-questions without inversion or do insertion is even possible.

Although the results of our analysis did not support our supposition of the overuse of do stemming from a greater proportion of nonsubject wh-questions in the input in the higher level textbooks, a re-examination of Hasebe and Maki's (2014) data suggests another possible explanation, namely the emergence of U-shaped learning. In this threephase process, learners initially adopt a correct form but then abandon it for an incorrect one before eventually returning to the correct one (Strauss, 1982), though most learners in Hasebe and Maki's (2014) study had yet to reach the final phase.

Matessa and Anderson (2000) showed that learners in the initial stages of second language acquisition tend to focus on only a single cue at a time. As it would happen, in addition to their findings with regard to asymmetries in wh-interrogative performance, Hasebe and Maki (2014) also affirmed the universal acquisition of yes/no questions before wh-questions. Thus, the interlanguage grammar of beginning-level learners can be imagined as treating do insertion and wh-subject extraction as mutually exclusive operations, with do essentially signaling the question when there is no copula, auxiliary, or wh-word. Ignoring the morphology of the main verb, appropriate application of such a rule would then produce target-like realizations of yes/no and wh-subject extraction interrogatives but not wh-object or wh-adjunct extraction questions (see Table 2).

Table 2. Emergent Development of Noncopular Main Verb Questions

\begin{tabular}{|c|c|c|c|c|}
\hline \multirow[b]{2}{*}{$\begin{array}{l}\text { Question } \\
\text { type }\end{array}$} & \multirow[b]{2}{*}{$\begin{array}{l}\text { do/ } \\
\text { wh- }\end{array}$} & \multirow{2}{*}{$\begin{array}{l}\text { Beginner level } \\
\text { Example expression }\end{array}$} & \multicolumn{2}{|r|}{ Intermediate/advanced level } \\
\hline & & & $\begin{array}{l}\text { do/ } \\
\text { wh- }\end{array}$ & Example expression \\
\hline Yes/No & $+/-$ & Did Tom [eat] the apple? & $+/-$ & Did Tom [eat] the apple? \\
\hline Subject & $-/+$ & Who [eat] the apple? & $+/+$ & Who did [eat] the apple?** \\
\hline Object & $-/+$ & What Tom $[e a t] ?^{* *}$ & $+/+$ & What did Tom [eat]? \\
\hline Adjunct & $-/+$ & When Tom [eat] the apple?** & $+/+$ & When did Tom [eat] the apple? \\
\hline & & Why Tom [eat] the apple?** & & Why did Tom [eat] the apple? \\
\hline
\end{tabular}

* = nontarget-like

As to why do insertion subsequently becomes associated with all noncopular main verb wh-questions, thus resulting in overgeneralization to cases of wh-subject extraction at the intermediate and advanced levels, Ellis (2002) explained that productive constructions (as opposed to irregular forms and idioms) are encoded as types (i.e., general classes or categories of similar linguistic items), not tokens (i.e., individual instances of specific items). In other words, the learner brain does not simply tabulate instances of who or what (with or without $d o$ ), but groups them into an abstraction 
with all other wh-words, which ostensibly serve the same general purpose (i.e., asking a non-yes/no question for which the answer contains neither a copular main verb nor an auxiliary). Once the learners' linguistic development allows them sufficient spare cognitive resources to notice the additional cue in the co-occurrence of $d o$ with the vast majority of all noncopular main verb wh-interrogative constructions, they apply do to the entire category indiscriminately, failing to distinguish the small number of instances of wh-words with which it does not actually appear.

For learners to move beyond this second phase and arrive back at target-like performance on noncopular main verb wh-subject questions, they need exposure to sufficient input to adjust their internalized cue weights (i.e., of wh-words in noncopular main verb questions with and without $d o$ ). However, frequency of exposure serves mainly to tune the interlanguage once an initial trace is registered (Ellis, 2002). For input (i.e., language to which one is exposed) to become intake (i.e., language that is successfully processed and used to inform one's mental representation of the linguistic system), learners must first not only notice it but also take stock of its relevant features (Schmidt, 1992). In other words, they must become conscious of the differential mappings of do with who and what according to their semantic roles. Moreover, they must internally process these forms within focused but meaningful activities (Vanpatten \& Cadierno, 1993). A simple example of a puzzle-type exercise designed to help raise this sort of awareness is provided in the Appendix.

Only once this initial noticing takes place can the learners begin to truly benefit from any implicit exposure they receive, but as MacWhinney (1997) put it, "From the viewpoint of psycholinguistic theory, providing learners with explicit instruction along with standard implicit exposure would seem to be a no-lose proposition" (p. 278). Although some instructors may at first be reluctant to teach the use of who, as opposed to whom, in the accusative case (i.e., as the object of a verb), it should be noted that two of the three textbook series in the present study included instances of the former but none showed any examples of the latter.

\section{Limitations}

Of course, all studies have their limitations, this one being no exception. First, many students use textbooks not examined here. In any case, textbooks are hopefully not their only sources of input. In short, the amounts and proportions of exposure to the different types of $w h$-questions presented here may not accurately represent those of the general Japanese JHS English learner population. Moreover, even if they do, not having analyzed any high school textbooks, we cannot discount the possibility that the do insertion issue is not already rectified at the next scholastic level. Nevertheless, by publishing these results, we hope to sensitize classroom instructors to the asymmetrical nature of whinterrogative acquisition and the possible need for explicit pedagogical intervention.

\section{Conclusion}

This study compared the three grade levels of three popular Japanese ministry-approved JHS English textbook series to determine whether Hasebe and Maki's (2014) observed stages of learner development of noncopular main verb wh-questions with and without do might be explained by differential exposure to these forms over the general course of study. Although the findings did not support this conjecture, the data revealed that these textbooks presented very little evidence at all of noncopular main verb wh-questions without $d o$ to prevent the overgeneralized use of $d o$ with all noncopular main verb wh-questions. Moreover, provision of additional implicit exposure to these forms may not suffice to rectify such eventual overgeneralization if the relevance of the wh-word's semantic role goes unnoticed. As such, JHS English instructors need to be sensitive to these subtle structural differences among wh-question types in order to sensitize their learners to them prior to providing them with the ever-necessary supplementary input.

\section{Bio Data}

Paul A. Lyddon is an associate professor in the Department of International Languages and Cultures in the School of International Relations at the University of Shizuoka, where he teaches graduate-level academic writing, among other subjects. He has a $\mathrm{PhD}$ in second language acquisition and teaching from the University of Arizona. $<$ palyddon@u-shizuoka-ken.ac.jp>

Hiromu Okamura is a student on the Cooperative Doctoral Course in Subject Development in the Graduate School of Education at Shizuoka University. His main interests include second language acquisition, syntax, and Japanese secondary school English education. He completed his master's degree at the University of Shizuoka, where his graduation thesis investigated the acquisition of wh-questions by Japanese learners of English on the basis of generative grammar. < hiromu_o0505@yahoo.co.jp>

\section{References}

de Villiers, J. (1991). Why questions? In T. L. Maxfield \& B. Plunkett (Eds.), Papers in the acquisition of wh: Proceedings of the UMass Roundtable, May 1990 (pp. 155-173). Amherst, MA: GLSA Publications. 
Ellis, N. C. (2002). Frequency effects in language processing: A review with implications for theories of implicit and explicit language acquisition. Studies in Second Language Acquisition, 24, 143-188. https://doi.org/10.1017/S0272263102002024

Ervin-Tripp, S. (1970). Discourse agreement: How children answer questions. In J. R. Hayes (Ed.), Cognition and the development of language (pp. 79-106). Wiley: New York, NY.

Hasebe, M., \& Maki, H. (2014). Acquisition of the wh-interrogative construction by Japanese junior high school EFL learners. In R. T. Miller, K. I. Martin, C. M. Eddington, A. Henery, N. Marcos Miguel, A. M. Tseng, A. Tuninetti, \& D. Walter (Eds.), Selected proceedings of the 2012 Second Language Research Forum: Building bridges between disciplines (pp. 76-88). Sommerville, MA: Cascadilla Proceedings Project. Retrieved from http://www.lingref.com/cpp/slrf/2012/ paper3087.pdf

Kairyudo. (2016a). Sunshine English course 1. Tokyo: Kairyudo.

Kairyudo. (2016b). Sunshine English course 2. Tokyo: Kairyudo.

Kairyudo. (2016c). Sunshine English course 3. Tokyo: Kairyudo.

Lee, J.-H. (2009). A subject-object asymmetry in the comprehension of wh-questions by Korean learners of English. Applied Linguistics, 31, 136-155. https://doi.org/10.1093/applin/amp015

Lee, S.-Y. (2008). Adjunct-argument asymmetry in the acquisition of inversion in wh-questions by Korean learners of English. Language Learning, 58, 625-663.

https://doi.org/10.1111/j.1467-9922.2008.00452.x

MacWhinney, B. (1997). Implicit and explicit processes: Commentary. Studies in Second Language Acquisition, 19, 277-282. https://doi.org/10.1017/S0272263197002076

Matessa, M., \& Anderson, J. R. (2000). Modelling focused learning in role assignment. Language \& Cognitive Processes, 15(3), 263-292. https://doi.org/10.1080/016909600386057

Pica, P. (2003). Second language acquisition research and applied linguistics. Working Papers in Educational Linguistics, 18(2), 1-26. Retrieved from https://files.eric.ed.gov/fulltext/ED478286. pdf

Sanseido. (2016a). New crown 1: English series new edition. Tokyo: Sanseido.

Sanseido. (2016b). New crown 2: English series new edition. Tokyo: Sanseido.

Sanseido. (2016c). New crown 3: English series new edition. Tokyo: Sanseido.

Schmidt, R. (1992). Awareness and second language acquisition. Annual Review of Applied Linguistics, 13, 206-226. https://doi.org/10.1017/S0267190500002476

Strauss, S. (1982). Introduction. In S. Strauss (Ed.), U-shaped behavioral growth (pp. 1-9). New York, NY: Academic Press. https://doi.org/10.1016/B978-0-12-673020-3.X5001-0

Stromswold, K. J. (1990). Learnability and the acquisition of auxiliaries (Doctoral dissertation, Massachusetts Institute of Technology). Retrieved from https://dspace.mit.edu/handle/1721.1/13715
Tokyo Shoseki. (2015a). New horizon English course 1. Tokyo: Tokyo Shoseki.

Tokyo Shoseki. (2015b). New horizon English course 2. Tokyo: Tokyo Shoseki.

Tokyo Shoseki. (2015c). New horizon English course 3. Tokyo: Tokyo Shoseki.

Vanpatten, B., \& Cadierno, T. (1993). Input processing and second language acquisition: A role for instruction, Modern Language Journal, 77, 45-57. https://doi.org/10.2307/329557

Appendix

Question Formulation

Awareness-

Raising Activity for

Differential Uses of

Who and Do 